DOI: http://dx.doi.org/10.33846/ghs6108

\title{
Pendampingan Pembuatan MP-ASI Berbahan Lokal Dengan Media Booklet Resep Terhadap Pertumbuhan Anak 6-24 Bulan di Wilayah Kerja Puskesmas Air Besar Desa Batu Merah Kecamatan Sirimau Kota Ambon
}

\author{
Michran Marsaoly (koresponden) \\ Jurusan Gizi, Poltekkes Kemenkes Maluku; michranmarsaoly20719@gmail.com \\ Nilfar Ruaida \\ Jurusan Gizi, Poltekkes Kemenkes Maluku; nilfarruaida74@gmail.com \\ Deby Nur Fajni \\ Jurusan Gizi, Poltekkes Kemenkes Maluku; nurfajni@gmail.com
}

\begin{abstract}
ABSTRAK
Pemberian MP-ASI lokal memiliki beberapa dampak positif, antara lain; ibu lebih memahami dan lebih terampil dalam membuat MP-ASI dari bahan pangan local sesuai dengan kebiasaan dan social budaya setempat, sehingga ibu dapat melanjutkan pemberian MP-ASI local secara mandiri; meningkatkan partisipasi dan pemberdayaan masyarakat sertamemperkuat kelembagaan seperti PKK dan Posyandu; memiliki potensi meningkatkan pendapatan masyarakat melalui penjualan hasil pertanian; dan sebagai sarana dalam pendidikan atau penyuluhan gizi. Tujuan Penelitian adalah untuk menganalisis pengaruh pendampingan Pembuatan MP ASI Berbahanl okaldengan media booklet resep terhadap pertumbuhan anak umur $6-24$ bulan. Jenis penelitian ini menggunakan pendekatan kuantitatif, metode yang digunakan dalam penelitian ini adalah Quasi-Experimental Design (eksperimensemu), dengan rancangan Pretest-Posttest Group Design. Sampel adalah 40 ibu yang memiliki anak umur 6 sampai dengan 24 bulan yang menetap di wilayah kerja Puskesmas Air Besar, Desa Batu Merah, Kecamatan Sirimau, Kota Ambon. Sampel dibagi menjadi dua kelompok yaitu kelompok perlakuan dan kelompok control. Kelompok pertama 20 ibu untuk kelompok perlakuan yaitu penyuluhan dengan metode ceramah dan pendampingan dengan media booklet dan 20 ibu untuk kelompok control yaitu penyuluhan dengan metode ceramah. Data yang dikumpulkan dianalisis dengan uji statistik yang dipakai adalah uji Pair T-test dan Wilcoxon. Hasil Penelitian menunjukkan pemberian penyuluhan mampu meningkatkan pengetahuan ibu pada kelompok control, sedangkan pada kelompok perlakuan tidak berpengaruh. Tidak ada pengaruh pendampingan terhadap pemberian MP ASI.
\end{abstract}

Kata kunci: MP-ASI; booklet resep; anak 6-24 bulan

\section{PENDAHULUAN}

\section{Latar Belakang}

MP-ASI merupakan makanan peralihan dari ASI ke makanan keluarga. Makanan Pendamping ASI adalah makanan atau minuman yang mengandung zat gizi, diberikan pada bayi atau anak usia 624 bulan guna memenuhi kebutuhan gizi selain dari Air Susu Ibu (1). Makanan pendamping ASI ini diberikan pada bayi karena pada masa itu produksi ASI semakin menurun sehingga suplai zat gizi dari ASI tidak lagi memenuhi kebutuhan gizi anak yang semakin meningkat sehingga pemberian dalam bentuk makanan pelengkap sangat dianjurkan.

Secara umum terdapat dua jenis MP-ASI yaitu hasil pengolahan pabrik atau disebut dengan MP-ASI pabrikan dan yang diolah di rumah tangga atau disebut dengan MP-ASI lokal. Mengingat pentingnya aspek sosial budaya dan aspek pemberdayaan masyarakat dalam kegiatan pemberian MP-ASI maka MP-ASI yang akan diberikan pada tahun 2006 yaitu MP-ASI lokal atau disebut juga "MP-ASI dapur ibu" (1).

Pemberian MP-ASI lokal memiliki beberapa dampak positif, antara lain; ibu lebih memahami dan lebih terampil dalam membuat MP-ASI dari bahan pangan lokal sesuai dengan kebiasaan dan sosial budaya setempat, sehingga ibu dapat melanjutkan pemberian MP-ASI lokal secara mandiri; meningkatkan partisipasi dan pemberdayaan masyarakat serta memperkuat kelembagaan seperti PKK dan Posyandu; memiliki potensi meningkatkan pendapatan masyarakat melalui penjualan hasil pertanian; dan sebagai sarana dalam pendidikan atau penyuluhan gizi (2).

Salah satu faktor dalam pemberian MP-ASI adalah pengetahuan ibu (3). Manfaat pemberian ASI eksklusif sangat eratkaitannya dengan pemberian MP-ASI dini. Hal ini sesuai dengan penelitian yang dilakukan Briawan (2007) diketahui bahwa faktor penghambat keberlanjutan pemberian ASI adalah pengetahuan dan keyakinan ibu bahwa bayi tidak akan cukup memperoleh zat gizi jika hanya 
diberi ASI sampai umur 6 bulan, ibu dalam penelitian ini meyakini bahwa MP-ASI dapat meningkatkan gizi pada bayi. Hasil penelitian Putra (2011) memperlihatkan 53,3\% ibu memiliki pengetahuan cukup tentang MP-ASI pada bayi. Hasil penelitian Elvi (2007) di Desa Limau Manis didapatkan bahwa 13 orang $(43,3 \%)$ mempunyai pengetahuan kurang, 13 orang $(43,3 \%)$ mempunyai pengetahuan cukup dan 2 orang $(6,7 \%)$ mempunyai pengetahuan yang baik. Hasil penelitian di Desa Rembun dapat disimpulkan bahwa mayoritas pengetahuan ibu tentang makanan pendamping ASI pada anak usia 624 bulan pada katagori cukup yaitu $64,4 \%$ (4).

Upaya dalam meningkatkan pengetahuan ibu, perlu dilakukan kegiatan penyuluhan kesehatan untuk meningkatkan pengetahuan dan sikap tentang kesehatan yang diperlukan oleh masyarakat sehingga akan memudahkan terjadinya perilaku sehat pada mereka (5). Penyuluhan kesehatan masyarakat adalah upaya memberdayakan individu, kelompok dan masyarakat untuk memelihara, meningkatkan dan melindungi kesehatan, melalui peningkatan pengetahuan, kemauan dan kemampuan, serta mengembangkan iklim yang mendukung, yang dilakukan dari, oleh dan untuk masyarakat, sesuai dengan sosial budaya dan kondisi setempat (6).

Penyuluhan kesehatan dapat dilakukan dengan menggunakan berbagai metode. Metode yang digunakan tergantung pada sasaran. Metode yang sering digunakan dalam memberikan penyuluhan adalah metode ceramah. Metode ceramah adalah suatu cara dalam menerangkan dan menjelaskan suatu ide, pengertian atau pesan secara lisan kepada sekelompok sasaran sehingga memperoleh informasi tentang kesehatan. Selain metode ceramah, adapula metode lain yang lebih efektif dalam merubah pengetahuan, sikap bahkan perilaku namun jarang digunakan dalam memberikan penyuluhan yaitu metode diskusi (5).

Selain Metode ceramah, metode lain yang sering dilakukan adalah menggunakan media. Salah satu media yang digunakan adalah booklet. Booklet adalah suatu media untuk menyampaikan pesan - pesan kesehatan dalam bentuk buku yang berisi tulisan dan gambar. Booklet merupakan sebuah buku kecil yang terdiri dari tidak lebih 24 lembar (7)

Beberapa penelitian menunjukkan bahwa penggunaan metode ceramah saja kurang efektif. Penelitian lain menyebutkan bahwa penggunaan booklet mampu meningkatkan pengetahuan responden. Dari latar belakang tersebut peneliti ingin melakukan penelitian mengenai pendampingan pembuatan MP-ASI berbahan lokal dengan media booklet resep terhadap pertumbuhan anak umur 6 -24 bulan.

\section{METODE}

Jenis penelitian ini menggunakan pendekatan kuantitatif, metode yang digunakan dalam penelitian ini adalah Quasi-Experimental Design (eksperimen semu), dengan rancangan PretestPosttest Group Design.

Desain penelitian ini dapat digambarkan sebagai berikut :

\section{Tahap 1}

Perlakuan $\quad 01 \rightarrow \mathrm{X} 1 \rightarrow 02$

Kontrol $\quad 01 \rightarrow \mathrm{X} 1 \rightarrow 02$

\section{Tahap 2}

Perlakuan $\quad \mathrm{O} 3 \rightarrow \mathrm{X} 2 \rightarrow \mathrm{O} 4 \rightarrow \mathrm{O} 5$

\section{Kontrol $\quad 03 \longrightarrow 04 \rightarrow 05$}

Keterangan :

O1: observasi pengetahuan ibu sebelum penyuluhan

O2 : observasi pengetahuan ibu sesudah penyuluhan

O3 : Observasi pemberian MP ASI sebelum pendampingan

O4 : Observasi pemberian MP ASI sesudah pendampingan

O5 : Observasi pertumbuhan Balita

$\mathrm{X} 1$ : Pemberian Penyuluhan dengan metode ceramah dan demonstrasi

X2 : Pendampingan pembuatan MP ASI dengan media booklet 
Lokasi dalam penelitian ini dilaksanakan di wilayah kerja Puskesmas Arbes Desa Batu Merah Kecamatan Sirimau Kota Ambon. Kelompok Perlakuan berlokasi di Gunung Malintang, sedangkan kelompok kontrol berlokasi di Kahena

Populasi dalam penelitian ini adalah seluruh ibu yang mempunyai anak umur 6-24 bulan yang menetap di wilayah kerja Puskesmas Air Besar Desa Batu Merah Kecamatan Sirimau Kota Ambon.

Sampel dalam penelitian ini adalah 40 (Empat puluh) ibu yang memiliki anak umur 6 sampai dengan 24 bulan yang menetap di wilayah kerja Puskesmas Air Besar Desa Batu Merah Kecamatan Sirimau Kota Ambon pembagian 20 ibu untuk kelompok perlakuan yaitu penyuluhan dengan metode ceramah dan pendampingan dengan media booklet dan 20 ibu untuk kelompok control yaitu penyuluhan dengan metode ceramah.

HASIL

Tingkat Pengetahuan Ibu

Tabel 1. Tingkat Pengetahuan Terhadap MP-ASI pada Kelompok Kontrol

\begin{tabular}{|l|c|c|c|c|}
\hline Tingkat Pengetahuan & Pre Test & $\%$ & Post Test & $\%$ \\
\hline Baik & 1 & 5 & 15 & 75 \\
\hline Cukup & 14 & 70 & 5 & 25 \\
\hline Kurang & 5 & 25 & 0 & 0 \\
\hline Total & 20 & 100 & 20 & 100 \\
\hline
\end{tabular}

Berdasarkan tabel tingkat pengetahuan terhadap MP-ASI dapat diketahui pada kelompok kontrol hasil dari Pretest menunjukan bahwa terdapat 1 responden (5\%) dengan tingkat pengetahuan kategori baik, dan 15 responden (70\%) dalam kategori cukup, serta 5 responden (25\%) dalam kategori kurang. Sedangkan untuk hasil dari post tes menunjukan bahwa terdapat 15 responden (75\%) dalam kategori baik, dan 5 responden (25\%) dalam kategori cukup.

Tabel 2. Tingkat Pengetahuan Terhadap MP-ASI pada Kelompok Perlakuan

\begin{tabular}{|l|c|c|c|c|}
\hline Tingkat Pengetahuan & Pre test & $\%$ & Post Test & $\%$ \\
\hline Baik & 1 & 5 & 17 & 85 \\
\hline Cukup & 16 & 80 & 3 & 15 \\
\hline Kurang & 3 & 15 & 0 & 0 \\
\hline Total & 20 & 100 & 20 & 100 \\
\hline
\end{tabular}

Berdasarkan tabel tingkat pengetahuan terhadap MP-ASI dapat diketahui pada kelompok perlakuan hasil dari Pre test menunjukan bahwa terdapat 1 responden (5\%) dengan tingkat pengetahuan kategori baik, dan 16 responden (80\%) dalam kategori cukup, serta 3 responden (15\%) dalam kategori kurang. Sedangkan hasil dari Post test menunjukan bahawa terdapat 17 responden (85\%) dengan kategori baik, dan 3 responden (15\%) dalam kategori cukup.

Tabel 3. Tabel Hasil Pengolahan Uji SPSS

\begin{tabular}{|l|l|r|r|r|r|}
\hline \multicolumn{2}{|c|}{} & \multicolumn{3}{|c|}{$\begin{array}{c}\text { Levene's Test for } \\
\text { Equality of Variances }\end{array}$} & \multicolumn{2}{c|}{$\begin{array}{c}\text { t-test for Equality } \\
\text { of Means }\end{array}$} \\
\cline { 3 - 6 } \multicolumn{2}{|c|}{ Equal } & F & Sig. & T & \multicolumn{1}{c|}{ Df } \\
\hline \multirow{2}{*}{ Pengetahuan } & Equal variances assumed &, 106 &, 747 & $-1,664$ & 38 \\
\cline { 2 - 7 } & Equal variances not assumed & & & $-1,664$ & 37,956 \\
\hline
\end{tabular}

Berdasarkan pengolahan menggunakan software SPSS dengan uji Independent Sample Test di dapatkan hasil sebagaimana terdapat pada tabel di atas. Dapat disimpulkan bahwa tingkat pengetahuan Pre dan Post tidak ada perbedaan pada kedua kelompok. 


\section{Pemberian MP-ASI}

Berdasarkan tabel 4 dapat diketahui bahwa di Kelompok Kontrol dalam pemberian MP ASI yang tepat sebelum penyuluhan sebesar $10 \%$ yaitu ada sebanyak 2 responden sedangkan pemberian MP ASI yang tidak tepat sebanyak $90 \%$ yaitu sebanyak 18 responden. Sedangkan pemberian MP ASI yang tepat sesudah penyuluhan sebesar $25 \%$ yaitu ada sebanyak 5 responden sedangkan MP ASI yang tidak tepat sebanyak $75 \%$ yaitu sebanyak 15 responden.

Tabel 4. Ketepatan Pemberian MP-ASI Kelompok Kontrol

\begin{tabular}{|c|c|c|c|c|}
\hline Pemberian MP-ASI & Sebelum & $\%$ & Sesudah & $\%$ \\
\hline Tepat & 2 & 10 & 5 & 25 \\
\hline Tidak Tepat & 18 & 90 & 15 & 75 \\
\hline Total & 20 & 100 & 20 & 100 \\
\hline
\end{tabular}

Tabel 5. Ketepatan Pemberian MP-ASI Kelompok Perlakuan

\begin{tabular}{|c|c|c|c|c|}
\hline Pemberian MP-ASI & Sebelum & $\%$ & Sesudah & $\%$ \\
\hline Tepat & 3 & 15 & 11 & 55 \\
\hline Tidak Tepat & 17 & 85 & 9 & 45 \\
\hline Total & 20 & 100 & 20 & 100 \\
\hline
\end{tabular}

Berdasarkan tabel pemberian MP ASI dapat diketahui bahwa di Kelompok Perlakuan sebelum diberi penyuluhan dan pendampingan terdapat $15 \%$ yaitu ada sebanyak 3 responden dalam kategori tepat dan terdapat $85 \%$ yang pemberian MP ASI tidak tepat sebanyak 17 responden. Sedangkan sesudah diberikan penyuluhan dan pendampingan terdapat $55 \%$ yaitu ada sebanyak 11 responden dalam kategori tepat dan terdapat $45 \%$ yaitu 9 responden yang pemberian MP ASI tidak tepat.

\section{Pertumbuhan}

Tabel 6. Pertumbuhan Balita Kelompok Kontrol

\begin{tabular}{|c|c|c|}
\hline Pertumbuhan & Jumlah & $\%$ \\
\hline Naik & 11 & 55 \\
\hline Tidak Naik & 9 & 45 \\
\hline Total & 20 & 100 \\
\hline
\end{tabular}

Berdasarkan tabel diatas dapat diketahui bahwa pada Kelompok Kontrol balita yang mengalami pertumbuhan dengan berat badan naik sebesar $55 \%$, yaitu sebanyak 11 balita sedangkan balita yang tidak mengalami kenaikan berat badan sebesar $45 \%$ yaitu sebanyak 9 balita.

Tabel 7. Pertumbuhan Balita Kelompok Perlakuan

\begin{tabular}{|c|c|c|}
\hline Pertumbuhan & Jumlah & $\%$ \\
\hline Naik & 13 & 65 \\
\hline Tidak Naik & 7 & 35 \\
\hline Total & 20 & 100 \\
\hline
\end{tabular}

Berdasarkan tabel pertumbuhan diatas dapat diketahui bahwa di Kelompok Perlakuan sebesar $65 \%$ (13 balita) mengalami kenaikan berat badan dan sebsar 35\% ( 7 balita) tidak mengalami kenaikan berat badan.

\section{Perbedaan MP-ASI Sebelum Dan Sesudah Pendampingan Pada Kelompok Kontrol}

Berdasarkan pengolahan menggunakan software SPSS dengan Non Parametic Test di dapatkan hasil sebagaimana terdapat pada tabel di atas. Dapat disimpulkan bahwa pemberian MP-ASI pada kelompok kontrol tidak ada perbedaan. 
Tabel 8. Tabel Hasil Uji SPSS Uji Non Parametic Test

Hypothesis Test Summary

\begin{tabular}{|c|c|c|c|}
\hline & Null Hypothesis & Sig. & Decision \\
\hline 1 & $\begin{array}{l}\text { The distributions of different waluefielated- } \\
\text { across Sebelum Kontrol and } \quad \text { Samples } \\
\text { Sesudah Kontrol are equally likelyhoNemar Test }\end{array}$ & $.250^{1}$ & $\begin{array}{l}\text { Retain the } \\
\text { null } \\
\text { hypothesis. }\end{array}$ \\
\hline
\end{tabular}

Asymptotic significances are displayed. The significance level is .05.

${ }^{1}$ Exact significance is displayed for this test.

Perbedaan MP-ASI Sebelum dan Sesudah Pendampingan Pada Kelompok Perlakuan

Tabel 9. Tabel Hasil Uji SPSS Uji Mc Nemar

Hypothesis Test Summary

\begin{tabular}{|c|c|c|c|c|}
\hline & Null Hypothesis & Test & Sig. & Decision \\
\hline 1 & $\begin{array}{l}\text { The distributions of different walu } \\
\text { across Sebelum Perlakuan and } \\
\text { Sesudah perlakuan are equally } \\
\text { likely. }\end{array}$ & $\begin{array}{l}\text { Ekelated- } \\
\text { Samples } \\
\text { MoNemar Test }\end{array}$ & $.021^{1}$ & $\begin{array}{l}\text { Rejeot the } \\
\text { null } \\
\text { hypothesis. }\end{array}$ \\
\hline
\end{tabular}

Asymptotic significances are displayed. The significance level is .05.

1 Exact significance is displayed for this test.

Berdasarkan pengolahan menggunakan software SPSS dengan uji McNemar di dapatkan hasil sebagaimana terdapat pada tabel di atas. Dapat disimpulkan bahwa pemberian MP-ASI pada kelompok perlakuan ada perubahan.

\section{Perbedaan Pertumbuhan Anak Pada Kelompok Perlakuan Dan Kontrol}

Tabel 10. Tabel Hasil Uji SPSS Uji Chi-Square

\begin{tabular}{|l|r|r|}
\hline \multicolumn{3}{|c}{ Test Statistics } \\
\hline & $\begin{array}{l}\text { Pertumbuhan } \\
\text { Perlakuan }\end{array}$ & $\begin{array}{c}\text { Pertumbuhan } \\
\text { Kontrol }\end{array}$ \\
\hline Chi-Square & $1,800^{\mathrm{a}}$ &, $200^{\mathrm{a}}$ \\
Df & 1 & 1 \\
Asymp. Sig. &, 180 &, 655 \\
\hline
\end{tabular}

a. 0 cells $(, 0 \%)$ have expected frequencies less than

5. The minimum expected cell frequency is 10,0 .

Berdasarkan pengolahan menggunakan software SPSS dengan uji Chi-Square di dapatkan hasil sebagaimana terdapat pada tabel di atas. Dapat disimpulkan bahwa pada pertumbuhan balita pada kelompok perlakuan dan kelompok kontrol tidak ada perbedaan.

\section{PEMBAHASAN}

Responden dalam penelitian ini berjumlah 40 ibu yang mempunyai anak umur $6-24$ bulan yang terdiri atas 20 ibu pada kelompok intervensi dan 20 ibu pada kelompok kontrol. Jenis kelamin anak sebagian besar adalah perempuan (52,5\%). Rata-rata umur anak adalah 12 bulan. Sebagian besar anak responden dengan status gizi baik $77,5 \%$ (berdasar $\mathrm{BB} / \mathrm{U}$ ). kebanyakan responden dengan pendidikan terakhir SMA dengan pekerjaan sebagai ibu rumah tangga.

Menurut Ezzat (2007) faktor yang berhubungan terhadap pemberian MP-ASI, sumber informasi terkait MPASI salah satunya adalah tingkat pendidikan ibu. Sejalan dengan Ezzat, penelitian Liaqat pada 2006 juga membuktikan bahwa pendidikan ibu memiliki hubungan positif terhadap status gizi anak yang diberikan MP-ASI dan pengenalan MP-ASI pada usia anak di atas 6 bulan.

WHO merekomendasikan untuk memberikan ASI secara eksklusif sampai bayi berusia 6 bulan dan memberikan MP-ASI sejak bayi berusia 6-24 bulan diteruskan dengan pemberian ASI sampai dengan usia 2 tahun atau lebih. Standar ini direkomnedasikan karena terbukti dapat menurunkan angka kematian anak dan meningkatkan kualitas hidup ibu sesuai dengan Millenium Development Goals 
keempat dan kelima. Risiko kematian balita yang diberikan ASI dan MP-ASI dengan baik dapat menurun sebsar $13 \%$. Pemberian MPASI yang tepat mulai usia enam bulan akan mengurangi risiko malnutrisi (8).

Makanan pendamping ASI (MP-ASI) merupakan makanan atau minuman tambahan yang mengandung zat gizi dan diberikan mulai usia 6 -24 bulan untuk memenuhi kebutuhan gizi selain dari ASI. Setelah bayi berusia 6 bulan, kebutuhan zat gizi makin bertambah seiring dengan pertumbuhan dan perkembangan bayi, sementara produksi ASI mulai menurun, karena itu bayi membutuhkan makanan tambahan sebagai pendamping ASI. Pemberian makanan tambahan yang tidak tepat kualitas dan kuantitasnya dapat menyebabkan gizi kurang yang berdampak pada gangguan pertumbuhan dan perkembangan apabila tidak segera diatasi (9).

MPASI merupakan makanan atau minuman yang mengandung zat gizi, diberikan kepada bayi atau anak usia 6--24 bulan, dan diberikan secara bertahap sesuai dengan usia serta kemampuan pencernaan bayi guna memenuhi kebutuhan gizi, selain ASI. MPASI dibutuhkan karena pada usia 6-24 bulan, ASI hanya menyediakan 1/2 kebutuhan gizi bayi, dan pada usia 12--24 bulan, ASI menyediakan $1 / 3$ dari kebutuhan gizinya (10). Selain itu, pada usia ini perkembangan bayi juga sudah cukup siap untuk menerima makanan lain sehingga MPASI harus diberikan pada saat bayi berusia enam bulan.

Menurut Peraturan Pemerintah Nomor 33 Tahun 2012, MPASI yang tepat sejak usia enam bulan dan meneruskan pemberian ASI sampai usia dua tahun merupakan pola pemberian makan terbaik untuk bayi sejak lahir sampai anak berusia dua tahun. Penerapan pola pemberian makan ini akan memengaruhi derajat kesehatan selanjutnya dan meningkatkan status gizi bayi. Agar pemberian MPASI terlaksana dengan baik, diperlukan pengetahuan yang baik pula mengenai MPASI. Pada dasarnya, pengetahuan merupakan hasil penginderaan terhadap suatu objek melalui panca indera manusia, yaitu penglihatan, pendengaran, penciuman, perasa, dan peraba. Pengetahuan juga diposisikan sebagai faktor predisposisi dari perilaku yang timbul pada seseorang. Dalam penelitian yang dilakukan Rohmatika (2012), dijabarkan bahwa 66,7\% pemberian MPASI yang baik dilakukan oleh kelompok ibu dengan tingkat pengetahuan baik tentang MPASI dan 16,7\% oleh kelompok ibu dengan tingkat pengetahuan cukup tentang MPASI. Oleh karena itu, jika pengetahuan tentang MPASI baik, diharapkan pula perilaku terhadap pemberian MPASI juga baik (11).

Hasil penelitian menunjukan bahwa terdapat perubahan dalam pemberian MP ASI baik pada kelompok control maupun kelompok perlakuan. Diketahui bahwa di Kelompok Kontrol dalam pemberian MP ASI yang tepat sebelum penyuluhan hanya sebesar 10\% yaitu ada sebanyak 2 responden saja sedangkan pemberian MP ASI yang tidak tepat sebanyak $90 \%$ yaitu sebanyak 18 responden. Setelah dilakukan penyuluhan dan demonstrasi terjadi perubahan pemberian MP ASI. Pemberian MP ASI yang tepat sesudah penyuluhan sebesar $25 \%$ yaitu ada sebanyak 5 responden sedangkan MP ASI yang tidak tepat sebanyak $75 \%$ yaitu sebanyak 15 responden.

Pada Kelompok Perlakuan sebelum diberi penyuluhan dan pendampingan terdapat $15 \%$ yaitu ada sebanyak 3 responden dalam kategori tepat dan terdapat $85 \%$ yang pemberian MP ASI tidak tepat sebanyak 17 responden. Sedangkan sesudah diberikan penyuluhan dan pendampingan terdapat $55 \%$ yaitu ada sebanyak 11 responden dalam kategori tepat dan terdapat $45 \%$ yaitu 9 responden yang pemberian MP ASI tidak tepat.

Dari hasil penelitian ini dapat disimpulkan bahwa terjadi perubahan pemberian bentuk MP ASI baik pada kelompok control juga pada kelompok perlakuan. Hal ini disebabkan karena baik pada kelompok control maupun kelompok perlakuan sama-sama mendapatkan edukasi yaitu penyuluhan dan demo. Berdasarkan uji statistic mc Neymar menunjukan hasil bahwa pada kelompok control terdapat beda perubahan ketepatan pemberian MP ASI. Sedangkan pada kelompok perlakuan tidak terdapat perubahan yang berarti. Hal ini kemungkinan disebabkan karena pendampingan yang dilakukan hanya dalam waktu sebentar.

Pertumbuhan (growth) menurut Soetjiningsih dan Ranuh, (2015) adalah perubahan yang bersifat kuantitatif, yaitu bertambahnya jumlah, ukuran, dimensi pada tingkat sel, organ, maupun individu. Sebagai contoh, anak bertambah besar bukan saja secara fisik, melainkan juga ukuran dan struktur organ-organ tubuh dan otak. Otak anak semakin tumbuh terlihat dari kapasitasnya untuk belajar lebih besar, mengingat, dan mempergunakan akalnya semakin meningkat. Anak tumbuh baik secara fisik maupun mental.

Berdasarkan hasil penelitian pertumbuhan balita pada kelompok control dan kelompok perlakuan balita yang mengalami pertumbuhan dengan berat badan naik sebesar $55 \%$, yaitu sebanyak 11 balita sedangkan balita yang tidak mengalami kenaikan berat badan sebesar $45 \%$ yaitu sebanyak 9 balita dan untuk Posyandu Harapan Jaya sebesar 65\% (13 balita) mengalami kenaikan berat badan dan sebsar 35\% (7 balita) tidak mengalami kenaikan berat badan. 
Berdasarkan Uji statistic dengan pendekatan Chi Square menggunakan variabel pertumbuhan pada kelompok balita kelompok control dan kelompok balita perlakuan tidak signifikan $(p>0.05)$. hasil yang didapatkan tidak memberikan hasil yang signifikan ini dikarenakan penelitian dilakukan dalam waktu singkat yaitu hanya dalam waktu 1 (Satu) bulan, sehingga untuk perubahan pertumbuhannya tidak terlihat.

Kartono dalam Sobur (2013), mendefinisikan pertumbuhan sebagai perubahan secara fisiologis sebagai hasil dari proses pematangan fungsifungsi fisik, yang berlangsung secara normal pada diri anak yang sehat, dalam peredaran waktu tertentu. Pertumbuhan sifatnya sementara, hanya terjadi sampai manusia mencapai kematangan fisik. Artinya, individu tidak akan bertambah tinggi atau besar, jika batas pertumbuhan tubuhnya telah mencapai tingkat kematangan. Jadi, yang dimaksud dengan pertumbuhan adalah berkembangnya ukuran fisik dan struktur tubuh yang dapat diukur dengan satuan panjang ataupun satuan berat

Menurut Potter \& Perry (2010) ciri-ciri pertumbuhan yaitu Pertumbuhan akan terjadi perubahan ukuran dalam hal bertambahnya ukuran fisik, seperti berat badan, tinggi badan, lingkar kepala, lingkar lengan, lingkar dada, dan lain- lain. Pertumbuhan dapat terjadi perubahan proporsi yang dapat terlihat pada proporsi fisik atau organ manusia yang muncul mulai dari masa konsepsi hingga dewasa.

Sebuah penelitian oleh Bassichhetto dan Rea tahun 2008 mengevaluasi mengenai efektivitas pelatihan Pemberian Makanan Bayi dan Anak terhadap perubahan pengetahuan, sikap dan praktik tenaga kesehatan termasuk dokter dan ahli gizi. Hasilnya menunjukkan adanya peningkatan pengetahuan yang signifikan setelah pelatihan PMBA tersebut (8). Pada penelitian Mardiah (2002) berupa intervensi pemberian MP-ASI pada anak usia 6-24 bulan disertai dengan pendidikan kepada ibu berupa penyuluhan yang dilakukan selama 2 minggu menunjukkan perubahan status gizi yaitu peningkatan berat badan yang bermakna cukup baik sebesar $0,39 \mathrm{~kg}$ pada anak usia $6-11$ bulan dan kenaikkan 0,49 kg pada kelompok anak usia 12-24 bulan. Penyuluhan gizi mempunyai pengaruh terhadap pola pikir dan tingkat kepedulian ibu untuk memberikan asupan makanan yang baik pada anaknya (12).

Hasil penelitian Aminah (2008) di Bogor menunjukkan ada perbedaan yang bermakna terhadap perubahan tumbuh kembang anak setelah mendapatkan penyuluhan dan simulasi MP-ASI selama 2 bulan.

Hasil penelitian ini sejalan dengan penelitian oleh Manikyamba et al (2015) tentang pengaruh pemberian edukasi gizi pada pengetahuan ibu terhadap pemberian MP-ASI. Dalam penelitian tersebut,uji statistik menunjukkan perubahan signifikan pada pengetahuan ibu tentang MP-ASI setelah diberikan edukasi gizi. Perbaikan tersebut meliputi pengetahuan MP-ASI terkait frekuensi dan kuantitas pemberian MP-ASI.

\section{KESIMPULAN}

Berdasarkan hasil dan pembahasan adapun kesimpulan yang dapat ditarik dari penelitian ini sebagai berikut Pemberian penyuluhan mampu meningkatkan pengetahuan ibu pada kelompok control, sedangkan pada kelompok perlakuan tidak berpengaruh.Tidak ada pengaruh pendampingan terhadap pemberian MP ASI.Hal ini kemungkinan disebabkan karena pendampingan yang dilakukan hanya dalam waktusebentar.Tidak ada pengaruh pendampingan MP ASI terhadap pertumbuhan. Hal ini kemungkinan disebabkan karena pemantauan pertumbuhanyang dilakukan hanya dalam waktu singkat (1 bulan).

\section{DAFTAR PUSTAKA}

1. Depkes RI. 2006. Pedoman Pemberian Makanan Pendamping ASI (MP-ASI), Jakarta. Depkes RI. 2008. Modul Pelatihan Bagi Tenaga Kesehatan Promosi Kesehatan di Puskesmas, Jakarta.

2. Sarbini, D. dan Rahmawaty, S., 2008. Pelatihan Pembuatan Mp-ASI Lokal Dengan Bahan Dasar BMC (Bahan Makanan Campuran) Untuk Balita Pada Kader Posyandu Di Wilayah Kerja Puskesmas Stabelan Surakarta.

3. Martini, 2009 "Tingkat Pengetahuan ibu Terhadap Pelaksanaan dan Pemberian MP-ASI"

4. Lestari, D. 2012. Tingkat Pengetahuan Ibu Tentang Makanan Pendamping ASI Pada Anak Usia 6-24 Bulan Di Desa Rembun Nogosari Boyolali. Surakarta: Skripsi STIKES Kusuma Husada.

5. Notoatmodjo, S. 2012. Promosi Kesehatan dan Ilmu Perilaku. Jakarta: Rineka Cipta.

6. Depkes RI. 2008. Modul Pelatihan Bagi Tenaga Kesehatan Promosi Kesehatan di Puskesmas, Jakarta

7. Suiraoka dan Supariasa, N. 2012. Media Pendidikan Kesehatan. Yogyakarta: Graha IImu 
8. Retno, A.S.,et al.2013. Pengaruh Pemberian Makanan Pada Bayi dan Anak terhadap Pengetahuan, Keterampilan, dan Motivasi Bidan Desa. Jurnal DIKESA Januari 2013 hal. 1 -20.

9. Mutalib 2017.Pengaruh Pemberian Makanan Pada Bayi dan Anak terhadap Pengetahuan ibu, dalam Firlia Ayu Arini, Nur Intania Sofia nita IMBI. Pengaruh Pelatihan Pemberian MP-ASI Kepada Ibu dengan Anak Baduta Di Kecamatan Sukmajaya Kota Depok Terhadap Pengetahuan dan Perilaku Pemberian MP-ASI. J Kedokteran dan Kesehatatan. Vol.13, No. 1, Januari 2017.

10. Kemenkes RI, Dirjen Bina Gizi.2014. Pedoman gizi seimbang. Kemenkes RI.

11. Notoatmodjo, S. 2010. Metodologi Penelitian Kesehatan. Jakarta: Rineka Cipta

12. Chandradewi, dkk. 2012. Pengaruh Penyuluhan Gizi terhadapa Pola Pemberian MP-ASI, Berat badan, Status gizi Anak usia 6-24 bulan di Kelurahan Selagalas Kota Mataram. Jurnal Kesehatan Prima Vol. 6 No. 1 Februari 2012 hal. 849 - 859 